\title{
Trade Collapses and Trade Slowdowns: Evidence from Some Central and Eastern European Countries
}

\author{
Marco Giansoldati \\ University of Trieste, Italy \\ mgiansoldati@units.it \\ Tullio Gregori \\ University of Trieste, Italy \\ tgregori@units.it
}

\begin{abstract}
World trade suddenly plummeted in the last quarter of 2008 after the bankruptcy of Lehman brothers and the subsequent meltdown in financial markets. Even if the following recovery was impressive, trade growth is now noticeably below trend. The anaemic momentum in global export volume questions whether the financial crisis has permanently changed the trade landscape. In this paper, we address trade elasticities in some Central and Eastern European economies by estimating a standard import function equation. We employ a dynamic panel Auto Regressive Distributed Lag model with the Common Correlated Effects Mean Group estimator to cope with cross-sectional dependence. The model is fit on a sample of eight countries over the period 1995:q1-2017:q1. First, we estimate long-run import elasticities with respect to GDP and the relative import price. Then, we discriminate between booms and slowdowns. Results confirm imports respond differently over the business cycle.
\end{abstract}

Key Words: World trade collapse, trade elasticities, CEECS, CCEMG JEL Classification: F14, F41, D57, G01

https://doi.org/10.26493/1854-6935.16.3-18

\section{Introduction}

After the fall of the iron curtain, practitioners started to quantify the trade potentials between the European and the Central and Eastern European Countries (CEECS). Scholars put considerable efforts to assess endowments in the periphery and the ability of CEECS to catch up with more advanced economies (Hamilton and Winters 1992; Wang and Winters 1992; Baldwin 1995). Yet, these early works and following contributions focus mostly on the export side. Since then, little effort has been placed on the import side, exception made for a few scattered works on single countries (Benácek, Prokop, and Višek, 2003; Mroczek and Rubazek 
2004; Benk et al. 2006) and panels (Reininger 2007). Our aim is to fill this gap analysing the behaviour of imports with a sample of eight CEECs (the Czech Republic, Estonia, Hungary, Latvia, Lithuania, Poland, Slovakia, and Slovenia).

We also address the impact of the great recession and the European debt crisis, as we provide estimates on import elasticities during the period 1995-2017, whilst distinguishing between expansions and slowdowns in the business cycle. Our research objective is to supply a tentative explanation on the interplay between import and price sensitiveness to GDP during tranquil times and recessions for the aforementioned countries. This is essential to get a better understanding on CEECs' trade response to the 2008-2009 financial turmoil and the following European sovereign debt crisis, and which type of policy action may help to further foster trade and growth in the European Union.

We base our analysis on the most recent advances in the nonstationary panel literature, taking also into account parameter heterogeneity. To this aim, we adopt the Common Correlated Effects Mean Group (CCEMG) estimator for dynamic Auto Regressive Distributed Lag (ARDL) models recently introduced by Chudik and Pesaran (2015). Results confirm our research hypothesis: CEECs' trade behaviour is dissimilar during periods of relatively rapid economic growth (expansions or booms), and periods of relative stagnation or decline (contractions or recessions). First, we find a standard result of the import function literature: the income elasticity is greater than one in the whole sample. However, it is not significantly different from zero during expansions, while it is hefty (2.55) during contractions. Second, the error-correction speed of adjustment term is larger (in absolute value) in downturns, suggesting that macroeconomic variables respond asymmetrically along the business cycle, i.e. the return to the long-run equilibrium is much quicker during slowdowns than during expansions. Finally, price elasticity is significantly negative in the whole sample only.

Our work contributes to the literature on the estimation of world trade elasticities (European Central Bank 2014; Slopek 2015; Martínez-Martín 2016) with an in-depth analysis on a set of CEECS that represents a growing part of the European Union, but received so far little attention. Our investigation also sheds fresh new light on the first great recession that post-communist economies have suffered since their transition to a market economy.

The paper is organized as follows. In the next section, we illustrate re- 
cent developments in world trade and present the literature underpinning import function specifications. The third section introduces a theoretically sound approach for the empirical analysis and describes the dataset, the fourth section discusses results, and the fifth section summarizes and sets directions for further research.

\section{Literature Review}

There is a large literature that provides estimates about price and income elasticities for both advanced and developing countries. These are pivotal for addressing a wide range of important policy issues such as trade liberalization, the stability of the foreign exchange market or a monetary union, and the sustainability of external deficits (Marquez 2002). The traditional import function is specified as a log-linear function of income and the relative price of imports. This approach dates back to the early 1940s (De Vegh 1941; Adler 1945; Hinshaw 1945). Yet, the most well known contribution is due to Houthakker and Magee (1969), who reckon import income elasticity is lower in developing countries than in developed ones. They report an overall elasticity of about 1.62 for 15 leading economies and a value of 1.5 in the United States. However, a value larger than unity has the puzzling implication that, in the absence of relative price increases, a country will change from a self-sufficient economy to one that eventually cannot pay for its imports.

Several years later, Goldstein and Khan (1985) publish a comprehensive survey on import elasticities, but all previous findings have been dismissed mostly because they derive from possibly spurious regression, as cointegration analysis was not yet introduced. Nonetheless, more recent long-run estimates are still in the range of those reported by previous authors (Clarida 1994; Reinhardt 1995; Senhadji 1998; Marquez 2002; Harb 2005). This literature addresses different specifications and employs heterogeneous econometric techniques, adding several explanatory variables apart from GDP and import prices. However, all these studies confirm income elasticity is larger in advanced countries than in emerging and developing ones.

Exception made from a few scattered contributions on some Eastern European countries (Benácek, Prokop, and Višek, 2003; Mroczek and Rubazek 2004; Benk et al. 2006), to the best of our knowledge, the only comprehensive analysis on import responsiveness in CEECS is due to Reininger (2007). This author estimates separately the elasticity of all the components of final demand in single countries and three panels includ- 
ing respectively 5,8 , and 12 economies. Final demand elasticities are quite small in both panel and country estimates, i.e. always below unity but Slovakia. Imports in CEECS appear to be mostly driven by investment and exports, while private and government consumption play a minor role. Unfortunately, this author does not provide any results about GDP elasticities. As we will discuss in the next section, a central tenet in the trade function approach is the unitary elasticity. The standard model implies import elasticities with respect to income and price are respectively equal to one and minus one. As reported above, empirical findings are often very different. This may be due to either the over simplified theoretical model or the noise introduced by the proxies (Harb 2005).

All the contributions about CEECs have been published before the great recession and the world trade collapse. Since then, the average annual growth rate of global trade suffered from a severe drop due to the financial crisis, moving from the $7.3 \%$ of the years $2003-2007$ to the $2.7 \%$ of 2008 and the subsequent breakdown $(-10.2 \%)$. Global trade bounced back (12\%), but its growth rate halved in the following year. Since then its pace has been stabilizing to values around $3 \%$, less than half of the average rate of expansion during the previous three decades. ${ }^{1}$ Global trade is now $17 \%$ below where it would be had it grown at pre-crisis trend after 2011, while world GDP is now only $3 \%$ below trend. The trade-to-GDP ratio ${ }^{2}$ was 1.8 over the period $1981-2007$, and declined to 1.1 in the following years (Jääskelä and Mathews 2015).

This surprising sluggish pace attracted the attention of scholars around the world, who tried to provide plausible explanations for such a phenomenon, despite not reaching a consensus (International Monetary Fund 2016; Martínez-Martín 2016). Indeed, researchers look at to what extent the current trend in the trade-to-GDP ratio is attributable to shortterm (cyclical) and/or long-term (structural) effects. Amongst those who focus on the former, Bussière et al. (2013), Duval et al. (2014), Ollivaud and Schwellnus (2015) address the role of the different components in final demand (private consumption, government purchases, investment, exports). Amongst those who look at the latter, at least four structural factors have been isolated. First, the deceleration in the expansion of global value chains (Constantinescu, Mattoo, and Ruta 2015). Second, the shift of manufacturing towards emerging markets, such as China, India, the Asian tigers and Eastern Europe (European Central Bank 2016). Third, the possible substitution effect between imports and inward FDI (Martínez-Martín 2016). Fourth, the surge of protectionism, in the form 
of tariff and non-tariff barriers (Evenett 2014). Our contribution does not belong to these strands of literature, as we place ourselves in the path traced by the seminal work by Freund (2009). This author computes the trade elasticity with respect to GDP during normal and contractionary periods and finds it is higher during slowdowns. Our effort is thus to follow her intuition and provide evidence of import responsiveness to income and relative prices for a selection of CEECS, before and after the 2008-2009 financial turmoil and the Euro crisis.

\section{Model Setting and Data}

Import demand functions can be derived either from producer or consumer theory. The former casts a standard cost minimization problem:

$$
C\left(P_{M}, P_{D}, Y\right)=\min _{M, D}\left[P_{M} M+P_{D} D: f(M, D)>Y\right] .
$$

Producers find the optimal bundle of imported inputs $(M)$ and domestic ones $(D$, i.e. capital and labour) to attain a given level of output $Y$, where $f(M, D)$ is a well-behaved production function (Kohli 1991). The demand for imports that minimizes cost is:

$$
M=\frac{\partial C\left(P_{M}, P_{D}, Y\right)}{\partial P_{M}} .
$$

If we assume constant returns to scale, the cost function is separable in prices and output, so that the import demand function is linearly homogeneous in $Y$ :

$$
M=\frac{\partial C\left(P_{M}, P_{D}\right)}{\partial P_{M}} Y
$$

If we deem $Y$ as income, then income elasticity is equal to one. This import function can be easily determined from a CES technology, or approximated by a translog with constant second order terms. Either way, it is given by:

$$
\ln M=\ln Y-\beta \ln \frac{P_{M}}{P_{D}},
$$

where $Y$ is aggregated demand, traditionally proxied by GDP or National Income. This is the linear model analysed in earlier studies as in Houthakker and Magee (1969) among others. It restricts the demand elasticity to unity, while the price elasticity must be negative.

Another strand of the literature focuses on consumers. Clarida (1994) assumes a representative agent who consumes both a domestic good $D_{t}$ and an imported one $M_{t}$ : 
TABLE 1 Summary Statistics

\begin{tabular}{lrrrrr}
\hline Variable & Observations & Mean & Std. dev. & Min & Max \\
\hline Import & 716 & 4.460 & 0.243 & 3.818 & 4.854 \\
GDP & 716 & 4.287 & 0.505 & 2.968 & 5.049 \\
Price & 712 & 0.085 & 0.148 & -0.142 & 0.750 \\
\hline
\end{tabular}

$$
\begin{aligned}
\max _{D_{t}, M_{t}, A_{t}} & =V \int_{t=o}^{\infty} e^{-\delta t} U\left(D_{t}, M_{t}\right) d t, \\
\text { s.t. } A & =r A_{t}+\bar{Y}_{t}-D_{t}-P_{t}^{M} M_{t},
\end{aligned}
$$

where $P_{t}^{M}=P_{M, t} / P_{D, t}$ is the relative price of imports as the domestic price is the numeraire, $\bar{Y}_{t}$ is labour income, $A_{t}$ assets, $r$ the interest rate and $\delta$ the subjective rate of time preference. Reinhart (1995) adopts a CobbDouglas utility function that allows specifying the steady state. This yields an import demand function as in (4) with $\beta=1$, and where $Y$ is the sum of labour and interest incomes. This framework provides several testable propositions. First, it suggests that permanent income $Y$ and the relative price suffice to describe the long-run behaviour of imports. Second, it assigns a well-defined role to the activity level and prices to affect trade flows because the Cobb-Douglas utility function implies income and price elasticities to be equal to one and minus one, respectively.

This model is parsimonious but suitable to address trade elasticities in eight Central and Eastern European countries: the Czech Republic, Estonia, Hungary, Latvia, Lithuania, Poland, Slovakia, and Slovenia. The source of the quarterly data for imports, exports, GDP and final demand components, as well as the series of import prices and GDP deflators, covering the period 1995:q1-2017:q1, is the OECD Economic Outlook database. We compute relative import prices taking the ratio of the import prices of goods and services for each country by the correspondent output (GDP) price. Summary statistics are shown in table 1. The time dimension of our panel for these new accession countries is anyway quite sizeable, as it ranges from 83 to 96 quarters.

\section{Estimation and Results}

An autoregressive distributed dynamic panel specification $\operatorname{ARDL}\left(P, Q_{1}\right.$, $Q_{2}$ ) represents the most appropriate approach to study the long-run behaviour of the macro variables under scrutiny. It can be modelled as follows: 


$$
m_{c, t}=\alpha_{c}+\sum_{j=1}^{P} \gamma_{c, j} m_{c, t-j}+\sum_{j=0}^{Q_{1}} \beta_{c, j}^{Y} y_{c, t-j}+\sum_{j=0}^{Q_{2}} \beta_{c, j}^{M} p_{c, t-j}+u_{c, t},
$$

where $m_{c, t}$ is the $\log$ of real imports of country $c$ at time $t, y_{c, t}$ is the log of real GDP, and $p_{c, t}$, is the log of the relative import price, whereas $u_{c, t}$ contains unobservables and the error terms $\epsilon_{c, t}$. This approach is able to account for cross-country heterogeneity and provides useful information on the short- and long-run behaviour of macroeconomic components since (7) can be rewritten into the traditional Error Correction Model:

$$
\begin{aligned}
\Delta m_{c, t}= & \delta_{c}+\varphi_{c}\left(m_{c, t-1}-\theta_{c, y} y_{c, t}-\theta_{c, p} p_{c, t}\right)+\sum_{j=1}^{P-1} \lambda_{m, j} \Delta m_{c, t-j} \\
& +\sum_{j=0}^{Q_{1}-1} \mu_{c, j} \Delta y_{c, t-j}+\sum_{j=0}^{Q_{2}-1} \rho_{c, j} \Delta p_{c, t-j}+u_{c, t},
\end{aligned}
$$

where $\varphi_{c}=-\left(1-\sum_{j=1}^{P} \gamma_{c, j}\right)$ is the Error Correction speed of adjustment term. Long run parameters can also be derived from equation ( 7$)$ :

$$
\begin{aligned}
\theta_{c, y} & =\frac{\sum_{j=1}^{Q_{1}} \beta_{c, j}^{Y}}{1-\sum_{j=1}^{P} \gamma_{c, j}}, \quad \theta_{c, p}=\frac{\sum_{j=1}^{Q_{2}} \beta_{c, j}^{M}}{1-\sum_{j=1}^{P} \gamma_{c, j}}, \\
\lambda_{m, j} & =-\sum_{l=j+1}^{P} \gamma_{c, l} \quad \text { for } j=1,2, \ldots, P-1, \quad \text { while } \\
\mu_{c, j} & =\sum_{l=j+1}^{Q_{1}} \beta_{c, j}^{Y} \text { for } j=1,2, \ldots, Q_{1}-1, \\
\rho_{c, j} & =\sum_{l=j+1}^{Q_{2}} \beta_{c, j}^{M} \quad \text { for } j=1,2, \ldots, Q_{2}-1 .
\end{aligned}
$$

Of particular interest are the long-run elasticities: $-\varphi_{c} \theta_{c, y}$ and $-\varphi_{c} \theta_{c, p}$. It is well known that the adoption of fixed effect estimates may lead to biased results in the computation of long-run elasticities when coefficients are not the same across panels (Pesaran 2015). However, the size of our sample allows us to estimate the slope parameter by country and we can solve this problem via the Mean-Group (MG) estimator, which averages individual slope parameters (Pesaran and Smith 1995). Pesaran, Shin, and Smith (1999) suggest an additional estimator that employs both pooling and averaging, labelled Pooled Mean Group (P MG), which allows the intercept, short-run coefficients, and error variances to be different across 
countries. Yet, the PMG imposes the long-run coefficients to be the same across groups.

To cope with unobserved common factors, we adopt the approach of adding averages computed from the entire panel. As suggested by Pesaran (2006), we introduce the cross-sectional means of the dependent and independent variables in the regression model to account for the presence of latent variables that affect imports. The Common Correlated Effects Mean Group estimator requires the number of covariates in the panel regression to be less than the available time-series observations for each country, and performs quite well even for a relatively small number of nations (Pesaran 2006). Yet, the correlation amongst cross-sectional observations within a panel is not addressed by the MG approach, and this may lead to possible biased estimates and inferential errors in the outcome of standard tests. To avoid these issues, the MG estimator requires no serial correlation in the residuals, a result that is usually achieved by employing additional lags in the specification.

Given these premises, our empirical approach unfolds through two steps. First, we chose the optimal lag length for each country employing the Schwartz Bayesian Criterion (B IC). Second, we impose the same number of lags for all the countries under scrutiny, selecting the lag structure, which is most frequent within the panel. We also employ the same lag order for the dependent and independent variables to reduce the risk of persistence in the regressors (Chudik and Pesaran 2015). By making use of these guidelines we build an $\operatorname{ARDL}(2,2,2)$, whose results are provided in table 2. We first estimate the model for the whole sample and then we deal with the possible divergent dynamics over the business cycle. Hence, the sample is split in two parts: one with the observations corresponding to slowdowns and the other one with the observations for tranquil times. Quarters fall into the definition of slowdowns when the change in GDP between the current and the previous quarter is lower than the mean. The opposite holds for better times. We observe these quarters are slightly less than half of the overall time span.

We report the estimates of long-run elasticity of income and relative import prices for the full sample in column 1, whereas the estimates for quarters in slowdowns and those recorded in better times are respectively reported in column 2 and 3.

Let us first focus on the plausibility of the Есм. Table 2 shows the error correction terms are always negative and largely significant. Hence, estimates are consistent with the error correcting behaviour. Exception 
TABLE 2 Estimation Results of the Error Correction Model

\begin{tabular}{|c|c|c|c|c|c|c|c|}
\hline \multirow[t]{2}{*}{ Variables } & & \multicolumn{2}{|c|}{ Full sample } & \multicolumn{2}{|c|}{ Slowdowns } & \multicolumn{2}{|c|}{ Better times } \\
\hline & & (1) & & (2) & & (3) & \\
\hline \multirow[t]{8}{*}{ Short-run } & $\mathrm{L} \Delta$.Imports & -0.068 & (0.048) & -0.051 & $(0.090)$ & $-0.096^{* *}$ & $(0.048)$ \\
\hline & L2 $\Delta$.Imports & 0.008 & $(0.025)$ & 0.043 & $(0.059)$ & $-0.087^{\star *}$ & $(0.034)$ \\
\hline & $\triangle . G D P$ & $0.672^{* * *}$ & $(0.204)$ & 0.326 & (o.343) & 0.243 & $(0.371)$ \\
\hline & $\mathrm{L} \Delta . \mathrm{GDP}$ & $0.386^{\star *}$ & $(0.176)$ & -0.084 & $(0.302)$ & $0.667^{*}$ & $(0.343)$ \\
\hline & L $2 \Delta . G D P$ & 0.141 & $(0.114)$ & $0.257^{*}$ & $(0.137)$ & 0.115 & $(0.343)$ \\
\hline & $\Delta$. Imp. Price & $-0.205^{* * *}$ & $(0.067)$ & $-0.281^{* * *}$ & (0.054) & -0.159 & $(0.125)$ \\
\hline & L $\Delta$. Imp. Price & 0.046 & (0.108) & 0.079 & $(0.110)$ & 0.032 & $(0.095)$ \\
\hline & L2 $\Delta$.Imp. Price & $0.081^{\star}$ & $(0.049)$ & $0.246^{\star \star}$ & $(0.123)$ & -0.047 & $(0.095)$ \\
\hline \multirow[t]{3}{*}{ Long-run } & ECM & $-0.133^{* * *}$ & $(0.026)$ & $-0.235^{* * *}$ & $(0.080)$ & $-0.062^{\star}$ & $(0.038)$ \\
\hline & GDP & $1.420^{* * *}$ & $(0.273)$ & $2.547^{* * *}$ & (0.675) & 0.786 & $(0.761)$ \\
\hline & Import Price & $-0.520^{*}$ & $(0.289)$ & 0.600 & (o.771) & -1.494 & $(1.434)$ \\
\hline \multicolumn{2}{|c|}{ Observations } & 688 & & 331 & & 357 & \\
\hline \multicolumn{2}{|c|}{ Number of groups } & 8 & & 8 & & 8 & \\
\hline \multicolumn{2}{|l|}{ R-squared } & 0.406 & & 0.548 & & 0.468 & \\
\hline \multicolumn{2}{|c|}{ Adjusted R-squared } & 0.270 & & 0.262 & & 0.169 & \\
\hline
\end{tabular}

NOTES Standard errors in parentheses. ${ }^{* * *} p<0.01,{ }^{* *} p<0.05,{ }^{*} p<0.1$.

made for slowdowns, absolute values are quite small yet. This points out a slow convergence towards long-run equilibria. For instance, during better times the system corrects its previous period disequilibrium at a speed of about $6 \%$. This indicates a modest adjustment for reaching a steady state. The system appears to be quite resilient, maybe because of the long memory of time series variables, while in bad times almost $24 \%$ of the disequilibrium is corrected in a quarter. Summing up, the overall speed is $13 \%$ only.

GDP elasticities are always greater than one. More precisely, column 1 reveals a $10 \%$ increase in GDP generates, ceteris paribus, a $14 \%$ increase in imports. This magnitude is consistent with the findings for developed countries of Hong (1999) and Marquez (2002). In addition, Harb (2005) records similar values that are at odds with the standard theory. As far as the relative price is concerned, the estimated coefficient is negative but different from zero only at the $10 \%$ level. This indicates that the set of countries under scrutiny are not largely influenced by price oscillations in the choice of the quantity to be imported. Yet, as we pinpoint 
below, this result hides heterogeneous dynamics that feature each nation.

When growth is sluggish, the long-run income elasticity is larger. In particular, a $10 \%$ rise in GDP generates, ceteris paribus, a $25 \%$ increase in the volume of imports, whilst import prices are now not significant and the associated coefficient is surprisingly positive. This result is consistent with Freund (2009) who finds trade is more responsive to GDP during global downturns than in better times for several reasons. First, in uncertain times people are inclined to reduce relationships with foreign firms and put more emphasis on trust and financing issues that may arise with a non-domestic counterpart. Second, firms may make extensive use of accumulated inventories when retail sales prospects are gloomy. Third, when GDP declines, protectionist measures are often introduced and they exacerbate the reduction in trade. This is one of the reasons advocated by Constantinescu, Mattoo and Ruta (2015) to explain the presence of structural factors affecting the long-term decline in trade elasticity in the aftermath of the 2008-2009 financial crisis. This does not apply to EU intra trade yet. Fourth, trade is measured in gross terms while GDP in value added. The widespread diffusion of global value chains might thus be associated with larger variations in trade that do not necessarily lead to proportional changes in value added (Ferrantino and Taglioni 2014). Fifth, manufacturing is more affected than tertiary by recessions. Goods represent the bulk of trade, whereas services represent a large and increasing part of GDP.

If we observe what takes place during better times, the slow convergence towards a long-run equilibrium is coupled with statistically insignificant income and price elasticity. Hence, it seems that during good times consumers and producers import goods and services without putting too much attention to the budget constraint, while in bad times there may be a flight from quality of domestic purchases as suggested by Chen and Juvenal (2016) for food products.

These results are not affected by serial correlation, as reported in table 3. We put a maximum of four lags in the Cumby-Huizinga test, which is the most appropriate lag-length when dealing with quarterly data. Our approach provides consistent estimates both when homoscedasticity is assumed, but also when this assumption is relaxed and we allow for heteroscedasticity, as shown in table 4 . Even at the fourth lag, there is no evidence of serial correlation in the residuals.

To shed some light on the presence of non-negligible diverse behaviour in CEECs, we report the coefficients of long-run income and price elas- 
TABLE 3 Cumby-Huizinga Test for Autocorrelation (Condit. to Homoscedasticity)

\begin{tabular}{|c|c|c|c|c|c|c|c|}
\hline \multicolumn{4}{|c|}{ но: $q=$ o (serially uncorrelated $)$} & \multicolumn{4}{|c|}{ но: $q=$ о (serially uncorrelated $)$} \\
\hline \multicolumn{4}{|c|}{ H 1: s.c. present at range specified } & \multicolumn{4}{|c|}{ H 1: s.c. present at range specified } \\
\hline Lags & $\chi^{2}$ & $d f$ & $p$ & Lag & $\chi^{2}$ & $d f$ & $p$ \\
\hline $1-1$ & 1.197 & 1 & 0.274 & 1 & 1.197 & 1 & 0.274 \\
\hline $1-2$ & 2.863 & 2 & 0.239 & 2 & 1.545 & 1 & 0.214 \\
\hline $1-3$ & 5.056 & 3 & 0.168 & 3 & 2.524 & 1 & 0.112 \\
\hline $1-4$ & 6.257 & 4 & 0.181 & 4 & 1.346 & 1 & 0.246 \\
\hline
\end{tabular}

NOTES Hо: disturbance is ma process up to order $q$; $\mathrm{H} 1$ : serial correlation present at specified lags $>q$.

TABLE 4 Cumby-Huizinga Test for Autocorrelation (Robust to Heteroscedasticity)

\begin{tabular}{|c|c|c|c|c|c|c|c|}
\hline \multicolumn{4}{|c|}{ но: $q=\mathrm{o}$ (serially uncorrelated) } & \multicolumn{4}{|c|}{ но: $q=$ о (serially uncorrelated) } \\
\hline \multicolumn{4}{|c|}{ H 1: s.c. present at range specified } & \multicolumn{4}{|c|}{ H 1: s.c. present at range specified } \\
\hline Lags & $\chi^{2}$ & $d f$ & $p$ & Lag & $\chi^{2}$ & $d f$ & $p$ \\
\hline $1-1$ & 0.801 & 1 & 0.371 & 1 & 0.801 & 1 & 0.379 \\
\hline $1-2$ & 1.712 & 2 & 0.425 & 2 & 1.217 & 1 & 0.270 \\
\hline $1-3$ & 2.794 & 3 & 0.425 & 3 & 1.719 & 1 & 0.190 \\
\hline $1-4$ & 3.245 & 4 & 0.518 & 4 & 0.801 & 1 & 0.371 \\
\hline
\end{tabular}

NOTES Hо: disturbance is ma process up to order $q$; $\mathrm{H} 1$ : serial correlation present at specified lags $>q$.

ticity at the country level in table 5. Columns 1 and 2 exhibit estimates for the full sample, while columns 3 and 4 display results during slowdowns and the last ones for better times.

Only four out of eight countries present a significant coefficient for the income elasticity, as shown in column 1. Values range from 1.26 of the Slovak Republic to 1.93 of Poland. Among these countries, all but Latvia have significant long-run import price elasticities. Yet, Lithuania displays an unexpected positive and significant value (column 2). If we turn our attention to the income elasticity during slowdowns (column 3), we observe that six out of eight countries show a significant coefficient. Values range from 1.17 of the Czech Republic to 1.88 of Slovenia. These results are consistent with the previous literature (Harb 2005). Conversely, price elasticity is significant only in three cases, namely the Czech Republic, Lithuania and Slovenia. However, there is only a negative value (the Czech Republic), while the other countries exhibit positive digits. Finally, if we consider better times, long-term income elasticity is positive and 
TAB LE 5 Country-Level Elasticities of Income and Price

\begin{tabular}{|c|c|c|c|c|c|c|}
\hline \multirow[t]{3}{*}{ Countries } & \multicolumn{2}{|c|}{ Full sample } & \multicolumn{2}{|c|}{ Slowdowns } & \multicolumn{2}{|c|}{ Better times } \\
\hline & IE & $\mathrm{PE}$ & IE & $P E$ & IE & $P E$ \\
\hline & (1) & (2) & (3) & (4) & (5) & (6) \\
\hline Czech Republic & $\begin{array}{c}0.579 \\
(1.841)\end{array}$ & $\begin{array}{c}-1.395 \\
(1.525)\end{array}$ & $\begin{array}{l}1.169^{\star *} \\
(0.666)\end{array}$ & $\begin{array}{c}-0.768^{\star} \\
(0.500)\end{array}$ & $\begin{array}{l}1.618^{* *} \\
(0.879)\end{array}$ & $\begin{array}{l}-0.712 \\
(0.890)\end{array}$ \\
\hline Estonia & $\begin{array}{c}0.311 \\
(0.830)\end{array}$ & $\begin{array}{c}-1.022 \\
(1.639)\end{array}$ & $\begin{array}{l}1.776^{\star *} \\
(0.765)\end{array}$ & $\begin{array}{c}1.265 \\
(1.398)\end{array}$ & $\begin{array}{l}-4.255 \\
(10.32)\end{array}$ & $\begin{array}{r}-10.030 \\
(20.11)\end{array}$ \\
\hline Hungary & $\begin{array}{c}2.529 \\
(2.470)\end{array}$ & $\begin{array}{c}0.655 \\
(2.446)\end{array}$ & $\begin{array}{c}5.887 \\
(8.526)\end{array}$ & $\begin{array}{c}-2.297 \\
(7.487)\end{array}$ & $\begin{array}{c}0.464 \\
(8.998)\end{array}$ & $\begin{array}{c}-2.263 \\
(10.35)\end{array}$ \\
\hline Latvia & $\begin{array}{l}1.048^{\star * *} \\
(0.293)\end{array}$ & $\begin{array}{c}-0.205 \\
(0.875)\end{array}$ & $\begin{array}{l}1.195^{\star *} \\
(0.685)\end{array}$ & $\begin{array}{c}0.330 \\
(1.539)\end{array}$ & $\begin{array}{c}0.961^{*} \\
(0.676)\end{array}$ & $\begin{array}{c}0.262 \\
(1.540)\end{array}$ \\
\hline Lithuania & $\begin{array}{l}1.520^{\star * *} \\
(0.188)\end{array}$ & $\begin{array}{l}0.525^{* *} \\
(0.277)\end{array}$ & $\begin{array}{l}1.591^{* * *} \\
(0.105)\end{array}$ & $\begin{array}{l}0.426^{* * *} \\
(0.158)\end{array}$ & $\begin{array}{c}2.516 \\
(2.297)\end{array}$ & $\begin{array}{c}-1.706 \\
(4.161)\end{array}$ \\
\hline Poland & $\begin{array}{l}1.938^{* *} \\
(1.015)\end{array}$ & $\begin{array}{l}-1.441^{\star *} \\
(0.712)\end{array}$ & $\begin{array}{c}5.324 \\
(14.02)\end{array}$ & $\begin{array}{c}5.285 \\
(25.68)\end{array}$ & $\begin{array}{l}1.881^{*} \\
(1.363)\end{array}$ & $\begin{array}{l}-0.617 \\
(0.904)\end{array}$ \\
\hline Slovakia & $\begin{array}{l}1.256^{* * *} \\
(0.481)\end{array}$ & $\begin{array}{l}-0.962^{* *} \\
(0.511)\end{array}$ & $\begin{array}{l}1.553^{* * *} \\
(0.555)\end{array}$ & $\begin{array}{c}-0.126 \\
(0.853)\end{array}$ & $\begin{array}{c}0.913 \\
(1.100)\end{array}$ & $\begin{array}{l}-1.487 \\
(1.304)\end{array}$ \\
\hline Slovenia & $\begin{array}{c}2.179 \\
(1.959)\end{array}$ & $\begin{array}{c}-0.313 \\
(3.580)\end{array}$ & $\begin{array}{l}1.882^{\star * *} \\
(0.277)\end{array}$ & $\begin{array}{c}0.687^{*} \\
(0.420)\end{array}$ & $\begin{array}{c}2.186^{*} \\
(1.446)\end{array}$ & $\begin{array}{c}4.604 \\
(11.69)\end{array}$ \\
\hline
\end{tabular}

NOTES IE - income elasticity, PE - price elasticity. Standard errors in parentheses. ${ }^{\star \star \star} p$ $<0.01,{ }^{* *} p<0.05,{ }^{*} p<0.1$.

significant for the Slovak Republic, Latvia, Slovenia and Poland (column 5). Values range from 0.96 of Latvia to 2.19 of Slovenia. Interestingly, as it can be noticed in column 6 , none of the countries exhibits significant long-run price elasticity coefficients.

\section{Conclusions}

The prolonged effects of the 2008-2009 financial crisis prompted the need for a better understanding of the long-run relationship between income, imports, and relative prices, amongst others. This is not just an academic curiosum but mostly a policy issue, as decision makers should take appropriate actions to avoid disrupting changes in international trade behaviour along the business cycle.

This paper addresses these issues estimating long-run import elasticities for a sample of eight Central and Eastern European countries over the period 1995:q1-2017:q1. To fulfil such a task, we make use of a very simple but parsimonious specification, and adopt an ARDL model with the 
CCEMG estimator to take into account country heterogeneity. We derive elasticities of GDP and the relative import price for the complete sample, during slowdowns and in better times, for the whole panel and for individual countries too.

Our results show macroeconomic variables behave differently along the business cycle. First, the return to the long-run equilibrium is much faster during slowdowns than in better times. Second, income elasticity is not significant during recoveries and booms, while it is positive during slowdowns and for the whole sample. This provides tentative evidence that imports are affected by variations of income with gloomy prospects of growth. Prudential reasons may push households to reduce consumption and to accumulate precautionary savings, whilst forcing companies to reduce the amount of inventories. Conversely, imports appear to be driven by animal spirits during expansionary periods as price elasticity is weakly significant for the complete sample only. Finally, when we look at country-level elasticities, outcomes mimic the panel evidence.

Our study is not based on a structural model that may require to endogenize consumers' and firms' behaviour in a general equilibrium setting. This is a drawback, but despite this shortcoming, we are the first to provide tentative but clear evidence that import adjustments to GDP variations are extremely heterogeneous across the countries under scrutiny. Policy makers at the national and international level, especially for those countries already in the Eurozone, should take stock of this aspect to adopt appropriate countermeasures in each circumstance. We are thus aware of the importance to provide an in-depth investigation at the mechanisms behind each country's behaviour along the business cycle. This is beyond the scope of the present contribution, but in the agenda for future research.

\section{Notes}

1 Data are available from https://data.worldbank.org/indicator/NE.EXP .GNFS.KD.ZG

2 As suggested by the literature, we use interchangeably the terms 'elasticity' and 'trade-to-GDP ratio,' despite being aware the former derives from theory, whereas the latter has more an empirical flavour.

\section{References}

Adler, J. 1945. 'United States Import Demand during the Interwar Period.' American Economic Review 35(3): 418-30. 
Baldwin, R. E. 1995. 'The Eastern Enlargement of the European Union.' European Economic Review 39 (3-4): 474-81.

Benácek, V., Prokop, L., and A. Višek. 2003. 'Determining Factors of the Czech Foreign Trade Balance: Structural Issues in Trade Creation.' CN B Working Paper 3, Czech National Bank, Prague.

Benk, S., Z. M. Jakab, M. A. Kovács, B. Pàrkànyi, Z. Reppa, and G. Vadas. 2006. 'The Hungarian Quarterly Projection Model (NEM).' Occasional Papers 6o, Magyar Nemzeti Bank, Budapest.

Bussière, M., G. Callegari, F. P. Ghironi, G. Sestieri, and N. Yamano. 2013. 'Estimating Trade Elasticities: Demand Composition and the Trade Collapse of 2008-09.' American Economic Journal: Macroeconomics 5 (3): 118-51.

Chen, N., and L. Juvenal. 2016. 'Quality and the Great Trade Collapse.' I m F Working Paper 16/30, International Monetary Fund, Washington, DC.

Chudik, A., and M. H Pesaran. 2015. 'Common Correlated Effects Estimation of Heterogeneous Dynamic Panel Data Models with Weakly Exogenous Regressors.' Journal of Econometrics 118 (2): 393-420.

Clarida, R. 1994. 'Cointegration, Aggregate Consumption, and the Demand for Imports: A Structural Econometric Investigation.' American Economic Review 84 (1): 298-308.

Constantinescu, C., Mattoo, A., and M. Ruta. 2015. 'The Global Trade Slowdown: Cyclical or Structural?' World Bank Policy Research Working Paper 7158, World Bank, Washington, DC.

de Vegh, L., 1941. 'Imports and Income in the United States and Canada.' Review of Economics and Statistics 23 (3): 130-46.

Duval, R., K. C. Cheng, K. Hwa Oh, R. Saraf, and D. Seneviratne. 2014. 'Trade Integration and Business Cycle Synchronization: A Reappraisal with Focus on Asia.' I m F Working Papers 2014-52, International Monetary Fund, Washington, DC.

European Central Bank. 2014. European Central Bank Monthly Bulletin, July.

- 2016. 'Understanding the Weakness in Global Trade: "What is the new normal?"' European Central Bank Occasional Paper 178, European Central Bank, Frankfurt am Main.

Evenett, S. J. 2014. The Global Trade Disorder: The 16th GTA Report. London: CEPR Press.

Ferrantino, M. J., and D. Taglioni. 2014. 'Global Value Chains in the Current Trade Slowdown.' Economic Premise 137, World Bank, Washington, DC.

Freund, C. 2009. 'The Trade Response to Global Downturns: Historical Evidence.' World Bank Policy Research Working Paper 5015, World Bank, Washington, DC. 
Goldstein, M., and M. Khan. 1985. 'Income and Price Effects in Foreign Trade.' In Handbook of International Economics, edited by R. Jones and P. Kenen, 2:1041-1105. Amsterdam and New York: North-Holland Elsevier.

Hamilton, C. B., and A. L. Winters. 1992. 'Opening up International Trade with Eastern Europe.' European Journal of Political Economy (7) 14: 77116.

Harb, N. 2005. 'Import Demand in Heterogeneous Panel Setting.' Applied Economics 37 (20): 2407-15.

Hinshaw, R. 1945. 'American Prosperity and the British Balance of Payments Problem.' Review of Economics and Statistics 27 (1): 1-9.

Hong, P. 1999. 'Import Elasticities Revisited.' Discussion Paper 10, Department of Economic and Social Affairs, United Nations, New York.

Houthakker, H., and S. Magee. 1969. 'Income and price Elasticities in World Trade.' Review of Economics and Statistics 51 (2): 111-25.

International Monetary Fund. 2016. 'Global Trade: What's Behind the Slowdown?' World Economic Outlook, October: 63-120.

Jääskelä J., and T. Mathews. 2015. 'Explaining the Slowdown in Global Trade.' Reserve Bank of Australia Bulletin, September, 39-46.

Kohli, U. 1991. Technology, Duality, and Foreign Trade. Ann Arbor, Mi: University of Michigan.

Marquez, J. 2002. Estimating Trade Elasticities. Boston, M A: Kluwer.

Martínez-Martín, J. 2016. 'Breaking down World Trade Elasticities: A Panel Eсм Approach.' Documentos de Trabajo 1614, Banco de España, Madrid.

Mroczek, W., and M. Rubaszek. 2004. 'Development of the Trade Links between Poland and the European Union in the Years 1992-2002.' Materiały i Studia 30, National Bank of Poland, Warsaw.

Ollivaud, P., and C. Schwellnus. 2015. 'Does the Post-Crisis Weakness of Global Trade Solely Reflect Weak Demand.' oEcD Economics Department Working Papers 1216, OECD, Paris.

Pesaran, M. H. 2006. 'Estimating and Inference in Large Heterogeneous Panels with a Multifactor Error Structure.' Econometrica 74 (4): 9671012.

- 2015. Time Series and Panel Data Econometrics. Oxford: Oxford University Press.

Pesaran, M. H., Shin, Y., and R. P. Smith. 1999. 'Pooled Mean Group Estimation of Dynamic Heterogeneous Panels.' Journal of the American Statistical Association 94 (446): 621-34.

Pesaran, M. H., and R. P. Smith 1995. 'Estimating Long-Run Relationships from Dynamic Heterogeneous Panels.' Journal of Econometrics 68 (1): 79-113. 
Reinhardt, C. 1995. 'Devaluation, Relative Prices, and International Trade: Evidence from Developing Countries.' IMF Staff Papers 42 (2): 290312.

Reininger, T. 2007. 'Factors Driving Import Demand in Central and Eastern European E U Member States.' Paper presented at the workshop International Trade \& Domestic Growth: Determinants, Linkages and Challenges, Vienna, 27 September.

Senhadji, A. 1998. 'Time-Series Estimation of Structural Import Demand Equations: A Cross-Country Analysis.' IMF Staff Papers 45 (2): 236-68. Slopek, U. D. 2015. 'Why Has Income Elasticity of Global Trade Declined?' Mimeo, Deutsche Bundesbank, Frankfurt am Main.

Wang, Z. K., and A. L. Winters. 1992. 'The Trading Potential of Eastern Europe.' Journal of Economic Integration 7(2): 113-31.

This paper is published under the terms of the Attribution-

NonCommercial-NoDerivatives 4.0 International (CC B Y-NC-ND 4.0)

License (http://creativecommons.org/licenses/by-nc-nd/4.o/). 